\title{
Fen Bilimleri Dersini Alan Kaynaştırma Öğrencilerinin Kaynaştırma Uygulamaları Sürecine İlişkin Görüşleri
}

\author{
Perceptions of the Inclusive Students on Inclusive \\ Processes in Science Courses
}

\author{
Mustafa UZOĞLU**, Hicran DENIZLİ***
}

\begin{abstract}
Öz: Bu araştırma, Fen Bilimleri dersini alan özel gereksinimli öğrencilerin kaynaştırma uygulamaları sürecindeki görüşlerinin belirlenmesi amacıyla yapılmıştır. Araştırmada özel durum yöntemi kullanılmıştır. Bu çalışmaya 2012-2013 eğitim öğretim yllında Giresun ilindeki ortaokullarda öğrenim gören 2 görme engelli, 2 ortopedik engelli, 3 zihinsel engelli olmak üzere toplam 7 özel gereksinimli öğrenci katılmıştır. Çalışmada açık uçlu sorulardan oluşan öğrenci anket formu veri toplama aracı olarak kullanılmıştır. Ortaya çıkarılan veriler içerik analizi ile kodlama yapılarak temalar ve kategoriler belirlenmiştir. Araştırmanın sonucunda kaynaştırma öğrencileri, etkinliklere tam anlamı ile katılamamaları, okul kitaplarının ve okulda yapılan sınavların kendilerine uygun olmaması, arkadaşları tarafından rahatsız edilmeleri gibi sorunlar yaşadıklarını ortaya koymuşlardır.

Anahtar Kelimeler: Kaynaştırma eğitimi, özel gereksinimli öğrenciler, görüşler, fen bilimleri
\end{abstract}

\begin{abstract}
This research was conducted to determine the opinions of the inclusive students taking Science course on the process of inclusion practices. The special case method was used in the research. A total of 7 students with special needs, including 2 with visual impairment, 2 with orthopaedic handicap, 3 with mental retardation, studying at secondary schools in Giresun city centre during 2012-2013 education year participated in this study. In the research, student questionnaire consisting of open-ended questions was used as data collection tool. Themes and categories were identified by encoding data obtained from the questionnaire with the contents analysis. At the result of the research, inclusive students put forth that they have problems such as not being able to take part in the activities thoroughly, unsuitability of textbooks and exams at school and being disturbed by their friends.

Keywords: Inclusive Education, students with special needs, opinions, science
\end{abstract}

\section{Giriş}

Dünya üzerindeki hemen hemen her ülkede özel eğitime muhtaç çocuklara, özel gereksinimli öğrencilerle birlikte aynı eğitim ortamlarında eğitim verilirken (Kalkan ve Özmen, 2013; Karacan, Kaba, Yenigün, Aydın ve Bayazıt, 2003) son yıllarda Dünya'da ve Türkiye'deki gelişmeler doğrultusunda her bireye eğitimde eşit imkanların verilmesi, sağlık ve ulaşım hizmetlerinden yararlanmaları (Cankaya ve Korkmaz, 2012; Güven ve Çevik, 2012; Sart, Ala, Yazlık ve Yılmaz, 2004) gibi haklar ile özel gereksinimli öğrencilerin normal akranları ile birlikte eğitim almaları (Batu, Kırcaali İftar ve Uzuner, 2004) giderek yaygınlaşmaya başlamıştır. $\mathrm{Bu}$ doğrultuda özel gereksinimli öğrencilerin eğitim eşitliğini en iyi şekilde uygulayabilmek, en az kısıtlayıcı ortam olan ve normal sınıflarda uygulanan "Kaynaştırma Eğitimi Uygulamaları" ile mümkün olabilmektedir (Cankaya ve Korkmaz, 2012).

Türkiye'de engelli çocukların eğitimleri başta Anayasa olmak üzere yasalarla güvence altına alınmış ve eğitimlerinde kaynaştırma ilkesi net bir şekilde belirtilmiştir (Eripek, 1978). Örneğin, 2006 yılında yürürlüğe giren Özel Eğitim Hizmetleri Yönetmeliği'nde kaynaştırma: "Özel eğitime ihtiyacı olan bireylerin eğitimlerini, destek eğitim hizmetleri de sağlanarak yetersizliği olmayan akranları ile birlikte resmî ve özel; okul öncesi, ilköğretim, orta öğretim ve yaygın eğitim kurumlarında sürdürmeleri esasına dayanan özel eğitim uygulamalarıdır” şeklinde

\footnotetext{
*Bu makale, Doç. Dr. Mustafa UZOĞLU'nun danışmanlığında Hicran Denizli'nin yüksek lisans tezinden üretilmiştir. **Giresun Üniversitesi Eğitim Fakültesi, İlköğretim Bölümü Fen Bilgisi Öğretmenliği ABD, Giresun, Türkiye, e-posta: mustafa.uzoglu@giresun.edu.tr

***Fen Bilimleri Öğretmeni, Şehit Basri Apaydın Ortaokulu, Giresun, Türkiye
} 
tanımlanmıştır. Özel Eğitim Hizmetleri Yönetmeliği'nin 23. maddesinin i bendinde: "Kaynaştırma yoluyla eğitimlerine devam eden öğrencilerin yetersizlik türü, eğitim performansı ve ihtiyacına göre; araç-gereç, eğitim materyalleri, öğretim yöntem ve teknikleri ile ölçme ve değerlendirmede gerekli tedbirler alınarak düzenlemeler yapılır" ibaresi yer almaktadır (Özel Eğitim Hizmetleri Yönetmeliği, 2006, md. 23).

Kaynaştırma uygulamalarının temel öğelerinden olan öğrencinin, kaynaştırma eğitimi sürecinde olumlu özellikler göstererek başarı duygusunu yaşaması uygulamanın etkili olmasında önemlidir. $\mathrm{Bu}$ başarının oluşturulmasında özel gereksinimli öğrencinin, normal gelişim gösteren akranlarını model alma ve onlarla iletişime geçerek sosyalleşmeye ihtiyacı vardır. $\mathrm{Bu}$ durumda kaynaştırma eğitiminin amaçlarından biri, normal gelişim gösteren öğrencilerin taşıdığ1 avantajları, özel gereksinimli öğrencilerin öğrenmelerinde kullanmaktır (Duman ve Koçak, 2013). Özel gereksinimli öğrencilerin farklılıklarını, öğretmen ve akranlarının kabul etmesi kaynaştırma öğrencisinin başarısı için önemli bir faktördür (Leatherman, 2007). Normal gelişim gösteren öğrencilerin, özel gereksinimli öğrencilere karş1 olan tutumlarının olumlu yönde sağlanması, bunun için gerekli bilgilerin verilerek özel gereksinimli öğrencileri anlamaları süreç için önemli rol oynamaktadır (Tuncer, Karasu, Altunay ve Güler, 2011). Bu öğrencilerin akranları tarafından anlaşılmaları ile sosyal destek oluşacak ve bu durum kaynaştırma uygulamalarının olumlu yönde ilerlemesini sağlayacaktır (Metin, 1992; Sucuoğlu ve Özokçu, 2005). Kaynaştırma uygulamasının olumlu yönde ilerleyebilmesi için başka bir önemli etken ise özel gereksinimli öğrencilerin her birinin ayrı ayrı özelliklerini bilmek ve dersi bireysel farklılıklara dayanarak planlamaktır. Öğretmen planladığı dersin işlenişinde özel gereksinimli öğrencileri teşvik etmeli ve onlara uygulama yaptırarak onları da sürece dahil etmelidir (Güven, 2011). Dolayısıyla özel gereksinimli öğrencilere yönelik etkili yöntemlerin kullanılması gerekir. Çünkü öğretmenler tarafından farklı etkinliklere yer verilmediği durumda sorunlar artacak ve süreç olumsuz yönde ilerleyecektir (Odluyurt, 2013). Dolayısıyla öğretmenlerin gözünden sorunların belirlenmesi ve çözümünde onlarla işbirliği yapılması önemlidir (Denizli ve Uzoğlu, 2016).

Ülkemizde kaynaştırma uygulamalarına dâhil olan özel gereksinimli öğrencilerin akademik başarılarına yönelik olarak yapılan çalışmalar yetersiz kalmaktadır. Öğrencilere yönelik gerçekleştirilen destek hizmetleri için gerekli koşullar sağlanabilmiş değildir (Eripek, 2004; Kesiktaş, 2006). Özellikle öğretmenlere sunulan hizmet içi eğitim uygulamaları ile öğretmenlerin özel eğitim hakkında bilgilendirilmesinin sağlanmasına karşın, öğretmenler tarafından edinilen bilgilerin sınıflarda uygulanması tam anlamıyla gerçekleşmemiştir (Sucuoğlu ve Akalın, 2010). Dolayısıyla kaynaştırma uygulamalarına katılan özel gereksinimli ögrencilere ve genel eğitim sınıflarında bu ögrencilerle iletişim halinde olan öğretmenlere özel eğitim destek hizmetlerin ve özel eğitim ile ilgili kalıcı bilgilerin ve uygulamaya dönük etkili yöntemlerin sunulmaması kaynaştırma uygulamalarının başarısız olarak algılanmasına neden olmakta ve uygulamanın yaygınlaşmasını da engellemektedir (Gürgür ve Uzuner, 2010).

Okuldaki tüm öğrenciler, öğretmen ve idareciler, okul personeli ve tüm öğrencilerin aileleri bu eğitimin bir parçası haline geldiğinden özel gereksinimli bireylerin eğitimi yalnızca "Özel Eğitim" alanını ilgilendiren bir konu olmamaktadır (Güven ve Çevik, 2012). Kaynaştırma uygulamaları normal eğitim ortamlarında sürdürüldüğünden özel gereksinimli öğrenciler tıpk1 diğer normal akranları gibi birçok ders ile karşılaşmaktadır. Bu derslerden birisi de öğrencilerde Fen okuryazarlığının oluşmasını sağlayan Fen Bilimleri dersidir. Fen Bilimleri dersinin programına bakıldığında da özel gereksinimli öğrencilerin ihtiyaçlarının dikkate alındığı görülmektedir. Bu programda öğrencilerin fen okuryazarlığının gelişmesi ve etkili öğrenme ortamlarının oluşması için bireysel farklılıkları, ihtiyaçları, bakış açıları, yetkinlik ve yetersizliklerinin önemi ifade edilmiştir (MEB, 2005).

Sonuç olarak bu araştırmanın amacı, Fen Bilimleri dersini alan özel gereksinimli öğrencilerin kaynaştırma uygulamaları sürecine ilişkin görüşlerini ortaya koymaktır. Araştırmanın amacı çerçevesinde şu sorulara yanıtlar aranmıştır:

Fen Bilimleri dersini alan özel gereksinimli öğrencilerin;

a. Süreçte karşılaştıkları sorunlar nelerdir? 
b. Ders sırasında etkinliklere katılma durumları nasıldır?

c. Kaynaştırma uygulamaları sürecinde kullanılan farklı yöntem ve tekniklere ilişkin görüşleri nelerdir?

d. Kaynaştırma uygulamaları sürecinde fiziki ortamın uygunluğuna ilişkin görüşleri nelerdir?

e. Kaynaştırma uygulamaları sürecinde karşılaştıkları sorunlara ilişkin önerileri nelerdir?

\section{Yöntem}

Yöntem 2012-2013 eğitim öğretim y1lında yürütülen çalışmada nitel araştırma yöntemlerinden özel durum çalışması yöntemi kullanılmıştır. Durum çalışmaları bir konu ya da durum üzerinde daha geniş ve derinlemesine bilgi toplama firsatı vermektedir (Büyüköztürk, Çakmak, Akgün, Karadeniz ve Demirel, 2013). Bu araştırmada Giresun ili ortaokullarındaki Fen Bilimleri dersini alan özel gereksinimli öğrencilerin kaynaştırma uygulamaları sürecine ilişkin görüşleri derinlemesine incelenmiștir.

\section{Çalışma Grubu}

Çalışmaya 2012-2013 eğitim öğretim yılında Giresun ilindeki ortaokullarda öğrenim gören 2 görme engelli, 2 ortopedik engelli, 3 zihin engelli olmak üzere toplam 7 özel gereksinimli öğrenci katılmıştır. Araştırma etiği doğrultusunda katılımcıların isimleri kullanılmamıştır. $\mathrm{Bu}$ nedenle katılımcı öğrenciler Ö1, Ö 2 kodları ile isimlendirilmiştir. Araştırmaya katılan öğrencilere ait bilgiler aynen yansıtılmış ve ayrıntılı olarak Tablo 1'de sunulmuştur.

Tablo 1

Öğrencilere Ait Demografik Bilgiler

\begin{tabular}{|c|c|c|c|c|c|c|c|c|c|c|}
\hline & Cin & & & iyesi & & & Öğgren & in Eng & & \\
\hline 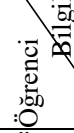 & 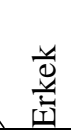 & $\underline{N}$ & $\begin{array}{l}\text { 帮 } \\
\text { in } \\
\text { in }\end{array}$ & 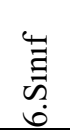 & 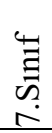 & $\begin{array}{l}\vec{\Xi} \\
\stackrel{D}{\infty} \\
\infty\end{array}$ & 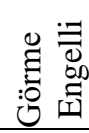 & 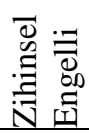 & 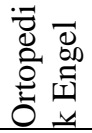 & 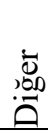 \\
\hline$\ddot{O}_{1}$ & & $\mathrm{x}$ & & & $\mathrm{x}$ & & & & $\mathrm{x}$ & \\
\hline$\ddot{\mathrm{O}}_{2}$ & & $\mathrm{x}$ & & $\mathrm{x}$ & & & & $\mathrm{x}$ & & \\
\hline $\mathrm{O}_{3}$ & & $\mathrm{x}$ & & $\mathrm{x}$ & & & & $\mathrm{x}$ & & \\
\hline$\ddot{O}_{4}$ & $\mathrm{x}$ & & & & & $\mathrm{x}$ & $\mathrm{x}$ & & & \\
\hline$\ddot{O}_{5}$ & $\mathrm{x}$ & & & $\mathrm{x}$ & & & $\mathrm{x}$ & & & \\
\hline$\ddot{O}_{6}$ & $\mathrm{x}$ & & & & & $\mathrm{x}$ & & & $\mathrm{x}$ & \\
\hline$\ddot{O}_{7}$ & $\mathrm{x}$ & & & & & $\mathrm{x}$ & & $\mathrm{x}$ & & \\
\hline
\end{tabular}

\section{Veri Toplama Aracı}

Araştırmada veri toplama aracı olarak açık uçlu sorulardan oluşan öğrenci anket formu kullanılmıştır. Anket, nitel araştırmada kullanılan en yaygın veri toplama yöntemlerindendir. Anket, araştırma problemi hakkında tüm soruların ayrıntılı bir şekilde belirlenmesini sağlamaktadır (Yıldırım ve Şimşek, 2013). Araştırmada kullanılan anket formu, araştırmacı tarafından hazırlanmış, uzman görüşleri doğrultusunda gerekli düzenlemeler yapılmış ve anket sorularına son şekli verilmiştir.

Anket formu 2 bölümden oluşmaktadır. Birinci bölüm demografik bilgilerden, ikinci bölüm ise kaynaştırma uygulamaları sürecine ilişkin görüşleri belirlemeye yönelik toplam 5 adet açı uçlu sorudan oluşmaktadır. Anket formu oluşturulduktan sonra geçerlililiği için ilk olarak Samsun Ondokuz Mayıs Üniversitesi Özel Eğitim Ana Bilim Dalında uzman bir öğretim üyesi, Karadeniz Teknik Üniversitesi Zihin Engelliler Öğretmenliği Ana Bilim Dalında uzman bir öğretim üyesi ve alanında uzman 15 yıllık devlet okullarında çalışmış bir özel eğitim öğretmeni tarafından incelenmiştir. Alınan dönütler doğrultusunda anket formu, Giresun Üniversitesi Fen Bilgisi Öğretmenliği Ana Bilim Dalında uzman üç öğretim üyesi ile tekrar incelenmiştir. Son hali verilen anket formu Fen Bilimleri dersini alan toplam 7 özel gereksinimli öğrenciye 
uygulanmıştır. Araştırmanın verileri, araştırmacı tarafından anket formlarının adaylara uygulanması ile toplanmıştır. Özel gereksinimli öğrencilerden görme engelli öğrencilerin cevapları anket formuna araştırmacı tarafından yazılmışırı. Çalışmada yansız davranılmaya dikkat edilmiştir. Veri toplama araci ile toplanılan veriler bulgular kısmında aynen yansıtılmıştır. Öğrencilerin anket formunu doldurma süreleri yaklaşık olarak 10-15 dakika sürmüştür.

\section{Verilerin Analizi}

Durum çalışmalarında veri toplama tekniklerinden biri de içerik analizidir (Çepni, 2007). İçerik analizi, verileri tanımlar ve verilere ait ayrıntıları ortaya çıkarır (Yıldırım ve Şimşek, 2013). Bu araştırmada, Fen Bilimleri dersini alan özel gereksinimli öğrencilerin sorulara verdikleri cevaplar bu araştırmanın verilerini oluşturmaktadır. Anket formundan elde edilen veriler içerik analizi ile kodlama yapılarak, kategoriler belirlenmiştir. Verilerin geçerliliğinin sağlanması için veriler, birden fazla araştırmacı ile analiz edilmiștir. İki araştırmacı öğrencilerin formdaki sorulara verdikleri cevapları genel olarak inceleyerek kodların ve temaların neler olacağına karar vermişlerdir. Daha sonra katılımcıların yanıtlarını, görüş birliğine varılan kodlara ve temalara göre sınıflandırmışlardır. Araştırmanın güvenirliği, Güvenirlik = Görüş birliği/Görüş birliği+Görüş ayrılığı.100 formülü kullanılarak hesaplanmıştır. İki araştırmacının yapmış oldukları kodlamalar arasındaki uyuşma oranının sorunlar için ortalamanın \% 80 seviyelerinde olduğu belirlenmiştir. Genellikle \% 70 ve üzerindeki değerler yeterli görülmektedir (Miles ve Huberman, 1994). Öğrencilerin vermiş oldukları cevaplar kullanılma sıklığına göre yorum katılmadan, yansız ve ayrıntılı bir şekilde bulgular kısmında sunulmuştur. Ayrıca tabloların altında verilerle ilgili gerekli yorum ve açıklamalar yapılmıştır.

\section{Bulgular}

Bu bölümde Fen Bilimleri dersini alan özel gereksinimli öğrencilerin kaynaştırma uygulamaları sürecindeki görüşlerine ilişkin bulgular yer almaktadır. Çalışmaya katılan öğrencilerin kaynaştırma uygulamalarına ilişkin bulguları tablolar halinde verilmiştir.

Tablo 2

Öğrencilerin Kaynaştırma Uygulamaları Sürecinde Gerçekleştirilen Etkinliklere Katılmalarına İlişkin Görüşleri

\begin{tabular}{cccc}
\hline Tema & Kod & \multicolumn{1}{c}{ Açıklamalar } & Kullanılma Sıklığı \\
\hline Etkinlikler & Kısmen Katılma & $\begin{array}{l}\text { Bazı Etkinliklerde Görev } \\
\text { Alınması }\end{array}$ & 3 \\
\cline { 2 - 4 } & Katılmıyorum & & 3 \\
\hline
\end{tabular}

Tablo 2 incelendiğinde özel eğitim öğrencilerinin kaynaştırma uygulamaları sürecinde gerçekleştirilen etkinliklere katılımına ilişkin görüşlerinin etkinlikler olarak 1 temada toplandığ 1 görülmektedir. $\mathrm{Bu}$ tema; kısmen kat1lıyorum (3), katılmıyorum (3) gibi alt gruplarda toplanmıştır. Öğrencilerden 3'ü bazı etkinliklerde görev aldıklarını ifade etmişlerdir. Örneğin Ö "Etkinliklerin bir kısmına katıldığını, öğretmenin öğrencileri kendisinin seçtiğini" vurgulamıştır. 3 öğrenci ise etkinliklere katılamadıklarını ifade etmiştir. Ö 4 "Deney yaparken herhangi bir ayrıcalık yapılmadığından deneylere katılmadığını", Ö ${ }_{1}$ "Ayakta yapılan etkinliklere katılamadığını" belirtmişlerdir. Etkinliklerin tamamına katılan öğrencinin bulunmadığı görülmektedir.

Tablo 3 incelendiğinde özel eğitim öğrencilerinin kaynaştırma uygulamaları sürecinde kullanılan farklı yöntem ve tekniklere yönelik görüşlerinin yöntem ve teknikler olarak 1 temada toplandığı görülmektedir. Bu tema; anlatım (2), deney (2), BDÖ (1), kullanmayanlar (3) gibi alt guruplarda toplanmıştır. Öğrencilerin $5^{\prime} i$ derste farklı yöntem ve tekniklere yer verildiğini belirtmiştir. Örneğin $\ddot{O}_{2}$ "Deneyler yapıldığını", Ö̈ "Slayttan izlediklerini", Ö 5 "Görme engelli olduğundan öğretmeninin şekil ve resimleri anlatım ile yaptığını" ifade etmişlerdir. 3 öğrenci ise 
Fen Bilimleri Dersini Alan Kaynaştırma Öğrencilerinin Kaynaştırma Uygulamaları Sürecine İlişkin Görüşleri

kendilerine yönelik herhangi bir yöntem ve tekniğin kullanılmadığını söylemişlerdir. Ö "Öğretmeninin dersi genel olarak anlattığını, farklı bir yöntem kullanmadığını" ifade etmiştir.

Tablo 3

Öğrencilerin Kaynaştırma Uygulamaları Sürecinde Kullanılan Farklı Yöntem ve Tekniklere İlişkin Görüşleri

\begin{tabular}{clllc}
\hline Tema & \multicolumn{2}{c}{ Kod } & \multicolumn{1}{c}{ Açıllamalar } & Kullanılma Sıklı̆̆ \\
\hline \multirow{3}{*}{ Yöntem } & Kullananlar & Anlatım & Basitleştirilmesi & 2 \\
ve Teknikler & & Deney & Somutlaştırılması & 2 \\
& & BDÖ & Görselleştirilmesi & 1 \\
\cline { 2 - 5 } & Kullanmayanlar & & $\begin{array}{l}\text { Dersin genel olarak } \\
\text { anlatılması }\end{array}$ & 3 \\
\hline
\end{tabular}

Tablo 4

Öğrencilerin Kaynaştırma Uygulamaları Sürecinde Fiziki Ortamın Uygunluğuna İlişkin Görüșleri

\begin{tabular}{|c|c|c|c|c|}
\hline \multirow{3}{*}{$\begin{array}{c}\text { Tema } \\
\text { Sinıfın Fiziki } \\
\text { Ortamının } \\
\text { Uygunluğu }\end{array}$} & \multicolumn{2}{|c|}{ Kod } & Açıklamalar & Kullanılma Sıklı̆̆ \\
\hline & Uygun & $\begin{array}{c}\text { Engel } \\
\text { Türü }\end{array}$ & $\begin{array}{l}\text { Fiziki ortamın engel türüne } \\
\text { göre olmas } 1\end{array}$ & 5 \\
\hline & \multicolumn{3}{|c|}{ Uygun Değil } & 2 \\
\hline
\end{tabular}

Tablo 4 incelendiğinde özel eğitim öğrencilerinin kaynaştırma uygulamaları sürecinde fiziki ortamın uygunluğuna ilişkin görüşlerinin sınıfın fiziki ortamın uygunluğu olarak 1 temada toplandığ 1 görülmektedir. Bu tema; engel türü (5), uygun değil (2) gibi alt gruplarda toplanmıştır. 5 öğrenci sınıfın fiziki ortamının engel türüne göre oluşturulması gerektiğine değinmiştir. Örneğin $\mathrm{O}_{2}$ "Malzemelere kolay ulaşabilmek için laboratuar ortamının daha uygun olduğunu" söylemiştir. 2 öğrenci ise bulundukları sınıfın fiziki ortamının kendileri için uygun olmadığını belirtmiştir. Ö 4 "Sıraların arasında yeterli boşluk olmadığını ve tek oturmak istemediğini" vurgulamıştır.

Tablo 5

Öğrencilerin Kaynaştırma Uygulamaları Sürecinde Sorun Yaşayıp Yaşamamalarına İlişkin Görüşleri

\begin{tabular}{ccclc}
\hline Tema & \multicolumn{1}{c}{ Kod } & \multicolumn{1}{c}{ Açıklamalar } & Kullanılma S1klığı \\
\hline \multirow{3}{*}{$\begin{array}{c}\text { Karşılaşılan } \\
\text { Sorunlar }\end{array}$} & \multirow{2}{*}{ Evet } & Öğretim & Okuma-yazma problemi & 2 \\
& & Arkadaş & Anlama problemi & 1 \\
& & Dişlanma problemi & 1 \\
\cline { 2 - 4 } & Hayır & & & 4 \\
\hline
\end{tabular}

Tablo 5 incelendiğinde özel eğitim öğrencilerinin kaynaştırma uygulamaları sürecinde herhangi bir sorun yaşayıp yaşamadıklarına ilişkin görüşlerinin karşılaşılan sorunlar olarak 1 temada toplandığı görülmektedir. Bu tema; öğretim (3), arkadaş (1), hayır (4) gibi alt gruplarda toplanmıştır. 3 öğrenci öğretim sürecinde okuma-yazma problemine, anlama sorununa ve ders sırasında rahatsız olduklarına değinmiştir. Örneğin Ö 7 "Kitaptaki yazıları okuyamadığını", Ö "Öğretmenin sorduğu soruları anlayamadığını", $\ddot{O}_{2}$ "Ders sırasında arkadaşlarının kendisini rahatsız ettiğini" belirtmişlerdir. Herhangi bir sorun yaşamayan 4 öğrenciden $\ddot{O}_{5}$ "Destek eğitiminde Fen Bilimleri dersi aldığı için derste bir sorun yaşamadığını" ifade etmiştir. 
Tablo 6

Öğrencilerin Kaynaştırma Uygulamaları Sürecinde Karşılaştıkları Sorunlara İlişkin Önerileri

\begin{tabular}{clcc}
\hline Tema & Kod & Açılklamalar & Kullanılma Sıklı̆̆ \\
\hline \multirow{4}{*}{ Sorunlar } & İlgi & Hoşgörülü olunması & 1 \\
& Ortam & Rahat bir ortamın sağlanması & 1 \\
& Merkerlendirme & Engel türüne dikkat edilmesi & 1 \\
& Merkezi Sınavlar & Engel türüne dikkat edilmesi & 2 \\
& Deneme Sınavları & Engel türüme dikkat edilmesi & 1 \\
\hline
\end{tabular}

Tablo 6 incelendiğinde özel eğitim öğrencilerinin kaynaştırma uygulamaları sürecinde ekledikleri düşüncelerinin sorunlar olarak 1 temada toplandığı görülmektedir. Bu tema; ilgi (1), ortam (1), değerlendirme (1), merkezi sinavlar (2), deneme sinavları (1) gibi alt gruplarda toplanmıştır. Öğrencilerden 2'si merkezi sınava yönelik önerilerde bulunmuştur. Örneğin Ö ${ }_{4}$ "Merkezi yapılan sınavların, okulda yapılan sınavlar gibi olması gerektiğini ve görsel soruların, şekillerin kaldırılmasını, paragrafların uzun olmamasını" ifade etmiştir. 1 öğrenci ilgiye yönelik, diğer 1 öğrenci ise bulundukları sınıf ortamına ilişkin önerilere yer vermişlerdir. Ö 6 "Engellilere karşı daha fazla ilgili olunmasını", Ö 5 "Düşüncelerini açıklayabilecekleri rahat ortamların oluşturulmasını" belirtmişlerdir.

\section{Tartışma / Sonuç ve Öneriler}

Özel eğitim öğrencilerinin kaynaştırma uygulamaları sürecinde gerçekleştirilen etkinliklere katılımına ilişkin görüşlerinin kullanılma sıklığına bakıldığında, kısmen katılıyorum (3) ve katılamıyorum (3) cevabını verdikleri görülmüştür. Kısmen katılıyorum diye görüş belirten öğrenciler, etkinlikte yer alan öğrencilerin öğretmenler tarafından seçildiğini ifade etmişlerdir. Etkinliklere katılamayan öğrenciler ise deneylerin yapıldığı sırada kendilerine yönelik olarak bir yardımın ve ayrıcalığın olmadığını vurgulamışlardır. Ulaşılan bu sonuç ile öğretmenlere etkinliklere katılım aşamasında, özel gereksinimli öğrencileri cesaretlendirme ve sınıf içerisinde olumlu bir ortam oluşturma gibi görevler düşmektedir. Araştırmada tespit edilen bu bulgular birçok araştırmanın sonucu ile benzerlik göstermektedir (Batu ve Oksal, 2013; Leatherman ve Niemeyer, 2005; Sucuoğlu ve Akalın, 2010). Nitekim Chhabra, Srivastava, R. ve Srivastava I. (2010), özel gereksinimli öğrenciler ile yaptıkları çalışmalarında öğrencilere yönelik olumsuz tutumların düşük beklentilere yol açtığını ve bunun sonucunda öğrenciler için öğrenme firsatlarının azaldığı bulgusu ulaştığımız sonuç ile benzerlik göstermektedir.

Özel eğitim öğrencilerinin kaynaştırma uygulamaları sürecinde herhangi bir sorun yaşayıp yaşamadıklarına ilişkin görüşlerinin kullanılma sıklığına bakıldığında, kitaptaki yazıları okuyamama (2) sonucu alanyazındaki diğer çalışmalar ile paralellik göstermektedir. Nitekim Topçu ve Katılmış (2013), yarı zamanlı kaynaştırma öğrencileri ile yaptıkları çalışmada katılımciların kendilerine sorulan sorulara cevap verememelerinde ders kitaplarının kendilerine uygun olmadığını ifade ettikleri görülmüştür. Bulgularda karşımıza çıkan bir başka sorun ise özel gereksinimli öğrencilerden biri arkadaşları tarafından rahatsız edildiğini ifade ermiş̧ir. $\mathrm{Bu}$ bulgu diğer çalışmaların bulguları ile paralellik göstermektedir (Akçamete ve Ceber, 1999). Karadağ, Yıldız Demirtaş ve Girli'nin (2014), okul öncesi öğrencileriyle yaptıkları çalışmalarında da özel gereksinimli öğrencilerin akranları tarafından düşük düzeyde kabul görüldüğü ya da görmezden gelindiği sonucu çalışmamızın sonuçları ile paralellik göstermektedir. Okul ortamında birlikte bulunan özel gereksinimli öğrenciler ile normal gelişim gösteren öğrencilerin ilk olarak birbirlerini anlamalarının ve birbirlerinin hakkında bilgi sahibi olmalarının önemli bir etken olduğu düşünülmektedir. Yapılan çalışmalarda da normal gelişim gösteren öğrencilerin özel gereksinimli öğrencilere karşı olumlu tutum geliştirmelerinin kaynaştırma sürecini olumlu yönde etkileyeceği bulguları dikkat çekmektedir (Duman ve Koçak, 2013; Kargın, 2004; Metin, 1992; Tuncer, Karasu, Altunay ve Güler, 2011). Nitekim Kargın ve Baydık (2002), kaynaştırma ortamındaki işiten öğrencilerin işitme engelli akranlarına yönelik tutumlarını inceledikleri çalışmalarında, işitme engeli ile ilgili bilgi alan öğrencilerin 
tutumlarının bilgi almayan öğrencilere göre daha olumlu olduğu bulgusu çalışmamızda ulaştığımız bulguları destekler niteliktedir.

Çalışmada bir öğrenci, öğretmen tarafından sorulan soruları anlayamadığını söylemiştir. Bu bulgu doğrultusunda dersin içeriğinin ve derste kullanılan yöntemlerin gözden geçirilmesi gerektiği düşünülmektedir. Ulaşılan bu sonuç Kaplan ve Çifci Tekinarslan'ın (2013), zihinsel yetersizliği olan ve olmayan öğrencilerin astronomi kavramlarındaki bilgi düzeylerinin karşılaştırılması isimli çalışmalarında, öğrencilerde kavram yanılgılarının olduğu ve bu durumun giderilmesi için çeşitli etkinlik ve yöntemlere yer verilmesi gerektiği bulgusu ile benzerlik göstermektedir. Bunun yanı sıra herhangi bir sorun yaşamadığı ifadesinin öğrenciler tarafından 4 kez kullanıldığı görülmüştür. Bu ifadeyi kullanan öğrencilerden birisi destek eğitiminde Fen Bilimleri dersi aldığını ve bu sebeple öğretim anlamında herhangi bir sorun yaşamadığını söylemiştir. Bu sonuç ile kaynaştırma eğitiminde, özel gereksinimli öğrencinin gelişimi için destek sınıfının önemi ortaya çıkmaktadır.Nitekim Gürgür, Kış ve Akçemete'nin (2012), çalışmalarında da öğretmen adayları, kaynaştırma eğitiminde uygulanan bireysel destek hizmetlerinin özel gereksinimli öğrencilerin akademik başarılarını artırdığını ve sosyal becerilerinin gelişmesine fayda sağladığını ifade etmişlerdir. Özel eğitim öğrencilerinin kaynaştırma uygulamaları sürecine ilişkin önerilerinin kullanılma sıklığına bakıldığında; engellilere yönelik olarak ilginin olması (1), düşüncelerini ifade edebilecekleri rahat ortamların oluşturulması (1), ders içerisinde sorulan soruların (1), merkezi (2) ve deneme sınavlarının (1) engel türüne dikkat edilerek yapılması gibi önerilerde bulundukları görülmüştür.

Özel eğitim öğrencilerinin kaynaştırma uygulamaları sürecinde derste kullanılan farklı yöntem ve tekniklere yönelik görüşlerinin kullanılma sıklı̆̆ına bakıldığında, konuların anlatıldığını (2), deneyler yapılarak dersin somutlaştırıldığını (2) ifade ettikleri görülmüştür. Derste farklı bir yöntem kullanılmadığı ifadesi ise öğrencilerden tarafından 3 kez kullanılmıştır. Literatürde yer alan bazı çalışmalarda özel gereksinimli öğrencilere farklı programlar uygulanarak derslerine olumlu katkıların olduğu tespit edildiği görülmüştür (Atik Çatak ve Tekinarslan, 2008; Biber Köse, 2009; Bülbül, 2013; Çulha, 2010; Güven ve Tufan, 2010; Kurcaali İftar ve Uysal, 1999; Karacan, Kaba, Yenigün, Aydın ve Bayazıt, 2003; Güldenoğlu ve Kargın, 2012; Kesiktaş, 2006; Odluyurt ve Batu, 2010; Yıldırım ve Tekin İftar, 2002). Nitekim Coşkun, Gür ve Aykutlu (2014), kaynaştırma öğrencilerinin okuduklarını anlamaları için sorulan sorulara sözel olarak ve resim yoluyla yanıtların alınmasını karşılaştırmışlardır. Öğrencilerin metine yönelik verdikleri cevaplarda sözel cevaba göre çizdikleri resimlerde metni daha iyi yansıttıkları ve daha çok ayrıntıya yer verdikleri görülmüsstür.

Özel eğitim öğrencilerinin kaynaştırma uygulamaları sürecinde fiziki ortama ilişkin görüşlerinin kullanılma sıklığına bakıldığında, malzemeler açısından laboratuar ortamının iyi olduğu (5), sıraların düzeni açısından ve tek oturmayı istemediklerinden dolayı fiziki ortamın uygun olmadığını (2) ifade ettikleri görülmüştür. Yapılan çalışmalarda da özel gereksinimli öğrencilerin bulunduğu okullarda sınıfın küçük ve kalabalık olması, okulların girişlerinde yer alan rampaların uygun olmaması, tuvaletlerde engelli tuvaletinin bulunmaması gibi kaynaştırma eğitimine uygun olmayan fiziksel koşulların bulunduğu tespit edilmiştir (Sadioğlu, Bilgin, Batu ve Oksal, 2013). Fiziksel düzenlemeler kaynaştırma uygulamalarında daha az alan bilgisine sahip düzenlemelerdir (Kargın, Güldenoğlu ve Şahin, 2010). Dolayısıyla hareket problemi yaşayan öğrencilere sınıflarında sırasına geçmesi için yardım etme gibi yapılan yardımların kaynaştırma eğitiminin önemli bir parçası olduğu unutulmamalıdır (Sorani Villanueva, McMahon, Crouch ve Keys, 2014).

Ülkemizde bireysel farklılıkların günden güne dikkate alındığı ve bireyselliğin ön planda olmasının sağlandığı kaynaştırma uygulamalarının başarısının özel gereksinimli öğrencilerin normal sınıflara yerleştirilmeleri ile sınırlı olduğu görülmektedir. Uygulama için gerekli olan okul koşulları, öğretmen, öğrenci ve veli işbirliği sağlanmış değildir. Çalışmada özel gereksinimli öğrencilerin ifade ettikleri sonuçlara bakıldığında öğretmenlerin kaynaştırma uygulamalarına yönelik olarak özel bir çaba sarf etmedikleri görülmüştür. Yapılan araştırmalar da özellikle öğretmenlerin kaynaştırma eğitimi konusunda kapsamlı bilgilerinin olmadığını ve bu konuda donanımlı bir şekilde eğitim almadıklarını ortaya koymaktadır (Altıntaş ve Şengül, 
2014; Altun ve Gülben, 2009; Babaoğlan ve Y1lmaz, 2010; Battal, 2007; Batu, 1998; Gaad ve Khan, 2007; Nayır ve Kepenekçi, 2013; Nonis, 2006). Kuşkusuz bu durum özel gereksinimli öğrencilerin eğitiminde birçok problemin oluşmasına neden olmaktadır. Bir başka bulguda öğrenciler ders sırasında kullanılan anlatım yöntemi ve sınıf içerisinde ki materyallerin, okulda yapılan sınavlar başta olmak üzere merkezi olarak yapılan "Temel Eğitimden Orta Öğretime Geçiş" sınavının kendilerine uygun olmadıklarını ifade etmişlerdir. Öğretmenlerin özel gereksinimli öğrencilere farklı sınavlar hazırladığı bir eğitim programında, Milli Eğitim Bakanlığının özel gereksinimli öğrencileri akranları ile aynı sınava tabi tutması kaynaştırma uygulamalarında bir çelişki oluşturmakta ve sadece okuldaki öğretmenlerin bireysel farklılıklara dikkat etmesi ile kaynaştırma uygulamalarının tam anlamı ile amacına ulaşamayacağı sonucu ortaya çıkmaktadır. Bu sonuçlar kaynaştırma uygulamalarının yasalarla desteklenmesine rağmen uygulamaya dönük eksikliklerin olması, kaynaştırma uygulamalarının eğitimdeki yerinin hala gerisinde olduğunu göstermektedir.

\section{Öneriler}

Kaynaştırma eğitiminde süreçte yer alan her bireye önemli görevler düşmektedir. Dolayısıyla her bireyin bu sürece yapacağı katkı, kaynaştırma uygulamalarının başarıya ulaşmasında birer adım olacaktır. Özellikle öğretmenlerin özel gereksinimli öğrenciler ile birebir ilgilenmesi kaynaştırma uygulamalarının başarıya ulaşmasında önemli bir etkendir. Dolayısıyla fiziksel altyapının düzenlenmesi ile sınıf mevcutlarının azaltılması ve kaynaştırma öğrencilerinin uygun bir dağılım ile sınıflara yerleştirilmesi ile öğretmenlerin özel gereksinimli öğrencilerle daha fazla ilgilenebilme imkanı bulabileceği düşünülmektedir.

\section{Kaynaklar}

Akçamete, G. ve Ceber, H. (1999). Kaynaştırılmış sınıflardaki işitme engelli ve işiten öğrencilerin sosyometrik statülerinin karşılaştırmalı olarak incelenmesi. Özel Eğitim Dergisi, 2(3), 64-74. Erişim adresi: http://dergipark.gov.tr/ozelegitimdergisi

Altıntaş, E. ve Şengül, S. (2014). The effects of special education courses on the attitudes of pre-service primary mathematics teachers towards mainstreaming. International Journal on New Trends in Education and Their Implications, 5(2), 103-113. Erişim adresi: http://www.ijonte.org/FileUpload/ks63207/File/10a.karakas.pdfcm6

Altun, T. ve Gülben, A. (2009). Okulöncesinde özel gereksinim duyan çocukların eğitimindeki uygulamalar ve karşılaşılan sorunların öğretmen görüşleri açısından değerlendirilmesi. Selçuk Üniversitesi Ahmet Keleşoğlu Ĕgitim Fakültesi Dergisi, 28, 253-272. Erişim adresi: http://www.acarindex.com/index.php?sayfa=sayidetay\&id=93

Atik Çatak, A. ve Tekinarslan, E. (2008). Powerpoint programında hazırlanan okuma materyalinin 12-13 yaşlarında kaynaştırma programına devam eden hafif düzeyde zihinsel engelli öğrencilerin okuduğunu anlama becerilerine etkisi. Abant İzzet Baysal Üniversitesi Eğitim Fakültesi Dergisi, 8(2), 207-124. Erişim adresi: http://dergipark.gov.tr/download/article-file/16655

Babaoğlan, E. ve Yılmaz, Ş. (2010). Sınıf öğretmenlerinin kaynaştırma eğitimindeki yeterlikleri. Kastamonu Eğitim Dergisi, 18(2), 345-354. Erişim adresi: http://www.kefdergi.com /pdf/18_2/18_2_1.pdf

Battal, İ. (2007). Sını ögretmenlerinin ve branş öğretmenlerinin kaynaştırma eğitimine iliş̧kin yeterliliklerinin değerlendirilmesi (Yayımlanmamış yüksek lisans tezi). Afyonkarahisar Kocatepe Üniversitesi Sosyal Bilimler Enstitüsü, Afyonkarahisar.

Batu, S. (1998). Özel gereksinimli ögrencilerin kaynaştırıldiğ bir kız meslek lisesinde ki ögretmenlerin kaynaştırmaya ilişkin görüş ve önerileri (Yayımlanmamış doktora tezi). Anadolu Üniversitesi Sosyal Bilimler Enstitüsü, Eskişehir.

Batu, S., Kırcaali İftar, G. ve Uzuner, Y. (2004). Özel gereksinimli öğrencilerin kaynaştırıldığ1 bir kız meslek lisesindeki öğretmenlerin kaynaştırmaya ilişkin görüş ve önerileri. Ankara Üniversitesi Eğitim Bilimleri Fakültesi Özel Eğitim Dergisi, 5(2), 33-50. DOI: 10.1501/Ozlegt_0000000082 
Biber Köse, S. (2009). Web destekli fen bilgisi ögretiminin kaynastırma ĕgitimindeki ilköğretim 7. sınıf ögrencilerinin performans düzeyi ve akademik basarılarına etkisi (Yayımlanmamış yüksek lisans tezi). Ege Üniversitesi Fen Bilimleri Enstitüsü, İzmir.

Bülbül, M. Ş. (2013). Görme engelli öğrenciler ile grafik çalışırken nasıl bir materyal kullanılmalıdır? Fen Bilimleri Öğretimi Dergisi, 1(1), 1-12. Erişim adresi: http://fead.org.tr/dergi/?page_id=137

Büyüköztürk, Ş., Çakmak, E. K., Akgün, Ö. E., Karadeniz, Ş. ve Demirel, F. (2013). Bilimsel araştırma yöntemleri. Ankara: Pegem Akademi.

Cankaya, Ö. ve Korkmaz, İ. (2012). İlköğretim 1. kademede kaynaştırma eğitimi uygulamalarının sınıf öğretmenlerinin görüşlerine göre değerlendirilmesi. Ahi Evran Üniversitesi Kırşsehir Eğitim Fakültesi Dergisi (KEFAD), 13(1), 1-16. Erişim adresi: http://kefad2.ahievran.edu.tr/archieve/pdfler/Cilt13Sayi1/JKEF_13_1_2012_1-16.pdf

Chhabra, S., Srivastava, R. ve Srivastava, I. (2010). Inclusive education in Botswana: The perceptions of school teachers. Journal of Disability Policy Studies, 20(4), 219-228. Erişim adresi: http://journals.sagepub.com/doi/10.1177/1044207309344690

Coşkun, İ., Gür, T. ve Aykutlu, H. (2014). Hafif düzey zihin engelli bireylerin okuduğunu anlama düzeyinin belirlenmesi ve yorumlanması amaciyla metin sonrası çizilen resimlerin incelenmesi. Uluslararast Avrasya Sosyal Bilimler Dergisi, 5(14), 17-42. Erişim adresi: http://www.ijoess.com/Makaleler/1526371564_ibrahim\%20coskun1742.pdf

Çepni, S. (2007). Araştırma ve proje çalışmalarına giriş. Trabzon: Celepler Matbaacılık.

Çulha, S. (2010). Zihinsel yetersizliği olan ilkögretim kaynaştırma ögrencilerine yabancı dil ögretiminde eşzamanlı ipucuyla sunulan bireysel destek eğitiminin etkililiği (Yayımlanmamış yüksek lisans tezi). Anadolu Üniversitesi Eğitim Bilimleri Enstitüsü, Eskişehir.

Denizli, H. ve Uzoğlu, M. (2016). Fen bilimleri dersi öğretmenlerinin kaynaştırma uygulamaları sürecine ilişkin görüşlerinin belirlenmesi. Part B: Türk Fen Eğitimi Dergisi, 13(1), 337.

Duman, G. ve Koçak, N. (2013). Anaokulu kaynaştırma sınıfında yer alan özel gereksinimli bir çocuğun sosyal oyun ve sosyal iletişim özellikleri. Cumhuriyet International Journal of Education, 2(3), 99-108. Erişim adresi: http://www.cijeonline.com/index.php/cije/issue /view/5

Eripek, S. (1978). Eğitilebilir geri zekâlı çocukların alt özel sınıflara seçimlerinde izlenen yöntem ve bu sınıfları bitiren çocukların durumlarının saptanması. Ankara Üniversitesi Eğitim Bilimleri Fakültesi Dergisi, 11(1), 269-291. DOI:10.1501/Egifak_0000000550

Eripek, S. (2004). Türkiye'de zihin engelli çocukların kaynaştırılmalarına ilişkin olarak yapılan araştırmaların gözden geçirilmesi. Ankara Üniversitesi Ë̆itim Bilimleri Fakültesi Özel Ĕ̈itim Dergisi, 5(2), 25-32. Erişim adresi: http://dergipark.gov.tr/download/articlefile/159201

Gaad, E. ve Khan, L. (2007). Primary mainstream teachers' attitudes towards inclusion of students with special educational needs in the private sector: A perspective from Dubai. International Journal of Special Education, 22(2), 95-108. Erişim adresi: http://www.internationaljournalofspecialed.com/issues.php

Güldenoğlu, B. ve Kargın, T. (2012). Karşılıklı öğretim tekniğinin hafif derecede zihinsel engelli öğrencilerin okuduğunu anlama becerileri üzerindeki etkililiğinin incelenmesi. Ankara Üniversitesi Ĕgitim Bilimleri Fakültesi Özel Ĕgitim Dergisi, 13(1), 17-34. DOI: 10.1501/Ozlegt_0000000164

Gürgür, H., Kış, A. ve Akçamete, G. (2012). Examining pre-service teachers opinions about providing individual support services to mainstreaming students. Elementary Education Online, 11(3), 689-701. Erişim adresi: http://ilkogretim-online.org.tr/index.php/io /article/ view/1480/1336

Gürgür, H. ve Uzuner, Y. (2010). Kaynaştırma sınıfında iş birliği ile öğretim uygulamalarına bakışın fenomenolojik analizi. Kuram ve Uygulamada Eğitim Bilimleri / Educational 
Sciences: Theory \& Practice, 10(1), 275-333. Erişim adresi: http://www.estp.com.tr/tr /tum-sayilar/

Güven, E. (2011). Müzik dersleri ve kaynaştırma uygulaması. Kastamonu Eğitim Dergisi, 19(3), 709-718. Erişim adresi: http://www.kefdergi.com/pdf/19_3/19_3_2.pdf

Güven, E. ve Çevik, D. B. (2012). Müzik öğretmeni adaylarının kaynaştırmaya ilişkin görüşlerinin belirlenmesine yönelik bir çalışma. Journal of Educatıonal and Instructional Studies in the World, 2(1), 2146-7463. Erişim adresi: http://www.wjeis.org /FileUpload/ds217232/File/22x.guven.pdf

Güven, E. ve Tufan, E. (2010). Kaynaştırma sınıflarında işbirlikli öğrenme yöntemi ile müzik dersleri. Uludă̆ Üniversitesi Eğitim Fakültesi Dergisi, 23(2), 557-573. Erişim adresi: http://dergipark.gov.tr/download/article-file/153421

Kalkan, S. ve Özmen E. R. (2013). A comparison of reading comprehension, reading rate and reading error performances of the students with mental retardation attending inclusive education and special education classes (The sample of Çorum province). International Online Journal of Educational Sciences, 5(1), 174-187. Erişim adresi: http://www.iojes.net//userfiles/Article/IOJES_828.pdf

Kaplan, G. ve Çifci Tekinarslan, İ. (2013). A comparison of knowledge levels of students with and without intellectual disabilities about astronomy concepts. Elementary Education Online, 12(2), 614-627. Erişim adresi: http://ilkogretim-online.org.tr/index.php/io /article/view/1424/1280

Karacan, Ç., Kaba, Z., Yenigün, Ö., Aydın, M. ve Bayazıt, B. (2003). Kaynaştırma grubu ile eğitilebilir zihinsel engelli grubun ritim ve dans çalışmaları yoluyla beceri düzeylerinde meydana gelen değişimlerin incelenmesi. $\dot{I}$. Ü. Spor Bilim Dergisi, 11(3), 132-136. Erişim adresi: http://dergipark.gov.tr/download/article-file/101414

Karadağ, F., Yıldız Demirtaş, V. ve Girli, A. (2014). Okul Öncesi Dönemde Akranların Sınıflarındaki Özel Gereksinimli Öğrenciyi Tercih Etme Durumları. Mehmet Akif Ersoy Üniversitesi Ë̆itim Fakültesi Dergisi, 1(31), 191-215. Erişim adresi: http://edergi.mehmetakif.edu.tr/index.php/efd

Kargın, T. (2004). Baş makale: Kaynaştırma: Tanımı, gelişimi ve ilkeleri. Ankara Üniversitesi Ĕgitim Bilimleri Fakültesi Özel Eğitim Dergisi, 5(2), 1-13. DOI:10.1501 /Ozlegt_0000000080

Kargın, T. ve Baydık, B. (2002). Kaynaştırma ortamındaki işiten öğrencilerin işitme engelli akranlarına yönelik tutumlarının çeşitli değişkenler açısından incelenmesi. Ankara Üniversitesi Ĕgitim Bilimleri Fakültesi Özel Eğitim Dergisi, 3(2), 27-39. DOI:10.1501 /Ozlegt_0000000064

Kargın, T., Güldenoğlu, B. ve Şahin, F. (2010). Genel eğitim sınıflarındaki özel gereksinimli öğrenciler için yapılması gereken uyarlamalara ilişkin sınıf öğretmenlerinin görüşlerinin incelenmesi.Kuram ve Uygulamada Ĕgitim Bilimleri, 10(4), 2431-2464. Erişim adresi: http://www.estp.com.tr/tr/

Kesiktaş, A. D. (2006). Ders çalışma becerileri ve özel gereksinimli öğrenciler. Ankara Üniversitesi Ĕgitim Bilimleri Fakültesi Özel Eğitim Dergisi, 7(1), 37-48. DOI:10.1501 /Ozlegt_0000000094

Kırcaali İftar, G. ve Uysal, A. (1999). Zihin özürlü öğrencilere özel eğitim danışmanlığı aracılığıyla uygulanan resimli fişlerle okuma-yazma öğretiminin etkililiği. Ankara Üniversitesi Ĕgitim Bilimleri Fakültesi Özel Ĕ̈itim Dergisi, 2(3), 3-13. DOI:10.1501 /Ozlegt_0000000046

Leatherman, J. M. (2007). "I just see all children as children": Teachers' perceptions about inclusion. The Qualitative Report, 12(4), 594-611. Erişim adresi: http://nsuworks.nova.edu /tqr/vol12/iss4/

Leatherman, J.M. ve Niemeyer, J.A. (2005). Teachers' attitudes toward inclusion: Factors influencing classroom practice. Journal of Early Childhood Teacher Education, 26(1), 23-36. http://www.tandfonline.com/doi/full/10.1080/10901020590918979 
MEB. (2005). İlköğretim Fen ve Teknoloji dersi (4-5. sinıflar) ögretim programı. Ankara: Devlet Kitapları Müdürlüğü Basımevi.

Metin, N. (1992). Okul öncesi dönemde özürlü çocuklar için kaynaştırma programları. Ankara Üniversitesi Eğitim Bilimleri Fakültesi Özel Eğitim Dergisi, 1(2), 34 -36. DOI: 10.1501/Ozlegt_0000000118

Miles, M. B. ve Huberman, A. M. (1994). Qualitative data analysis. Thousand Oaks, CA: Sage Publication.

Nayır, F. ve Kepenekci, K. Y. (2013). Kaynaştırma öğrencilerinin haklarına ilişkin sınıf öğretmenlerinin görüşleri. Eğitim Bilimleri Araşstırmaları Dergisi, 3(2), 69-89. Erişim adresi: http://ebad-jesr.com/images/MAKALE_ARSIV/C3_S2makaleler/3.2.05.pdf

Nonis, K. P. (2006). Integrating children with special needs: Singapore preschool teachers share their feelings: A preliminary investigation. Journal of the International Association of Special Education, 7(1), 4-10. Erişim adresi: http://www.ndsl.kr/ndsl/search/detail /article/articleSearchResultDetail.do?cn=NART28789505

Odluyurt, S. (2013). Kaynaştırmaya devam eden otistik özellikler gösteren çocuklara kurallı oyun öğretiminde akranları tarafından doğrudan model olma ve videoyla model olma öğretiminin etkilerinin karşılaştırılması. Kuram ve Uygulamada Eğitim Bilimleri / Educational Sciences: Theory \& Practice, 13(1), 523-540. Erişim adresi: http://www.kuyeb.com /pdf/tr/c6146cc622c03e850055e70aaf46da0623540.pdf

Odluyurt, S. ve Batu, E. S. (2010). Gelişimsel yetersizlik gösteren çocuklara kaynaştırmaya hazırlık becerilerinin öğretimi. Eğitim Bilimleri Dergisi, 10(3), 1533-1572. Erişim adresi: http://www.kuyeb.com/pdf/tr/4f6f734c00ac6c4220b501ec632d115dtFULL.pdf

Özel Eğitim Hizmetleri Yönetmeliği. (2006, 31 Mayıs) Resmi Gazete. (26184). Erişim Adresi: https://orgm.meb.gov.tr/meb_iys_dosyalar/2012_10/10111226_ozel_egitim_hizmetleri_ yonetmeligi_son.pdf

Sadioğlu, Ö., Bilgin, A., Batu, S. ve Oksal, A. (2013). Problems, expectations, and suggestions of elementary teachers regarding inclusion. Educational Sciences: Theory \& Practice, 13(3), 1760-1765. DOI: 10.12738/estp.2013.3.1546

Sart, Z. H., Ala, H., Yazlık, Ö. ve Yılmaz, F. K. Türkiye kaynaştırma eğitiminde nerede? Eğitimciye öneriler. XIII. Ulusal Eğitim Bilimleri Kurultay1, 6-9 Temmuz 2004, Malatya-Türkiye.

Sorani Villanueva, S., McMahon, S. D., Crouch, R. ve Keys, C. B. (2014). School problems and solutions for students with disabilities: A qualitative examination. Journal of Prevention \& Intervention in The Community, 42(1), 58-71. Erişim adresi: http://www.tandfonline.com/doi/full/10.1080/10852352.2014.855060?src=recsys

Sucuoğlu, B. ve Akalın, S. (2010). Kaynaştırma sınıflarına alternatif bir bakış: Çevresel davranışsal değerlendirme ile öğretimsel özelliklerin incelenmesi. Ankara Üniversitesi Ĕgitim Bilimleri Fakültesi Özel Eğitim Dergisi, 11(1), 19-37. DOI: 10.1501 /Ozlegt_0000000144

Sucuoğlu, B. ve Özokçu, O. (2005). Kaynaştırma öğrencilerinin sosyal becerilerinin değerlendirilmesi. Ankara Üniversitesi Eğitim Bilimleri Fakültesi Özel Ĕ̈itim Dergisi, 6(1), 41-57. DOI:10.1501/Ozlegt_0000000086

Topçu, E. ve Katılmış, A. (2013). Yarı zamanlı kaynaştırma eğitimi alan ortaokul öğrencilerinin sosyal bilgiler dersine yönelik düşünceleri. Sakarya University Journal of Education, 3(3), 48-81. Erişim adresi: http://suje.sakarya.edu.tr/

Tuncer, A. T., Karasu, N., Altunay, B. ve Güler, Ö. (2011). Türkçe ilköğretim kitaplarında engel ve engellilik: Bir doküman analizi örneği. Gazi Eğitim Fakültesi Dergisi, 31(2), 439457. Erişim adresi: http://gefad.gazi.edu.tr/article/view/5000078452/5000072673

Yıldırım, A. ve Şimşek, H. (2013). Sosyal bilimlerde nitel araştırma yöntemleri. Ankara: Seçkin Yayıncilik.

Yıldırım, S. ve Tekin İftar, E. (2002). Akranların sunduğu sabit bekleme süreli öğretim gelişimsel geriliği olan öğrencilere tanıtıı levhaların öğretiminde etkili midir? Ankara 
Üniversitesi Eğitim Bilimleri Fakültesi Özel Eğitim Dergisi, 3(2), 67-84. DOI:10.1501/ Ozlegt_0000000060

\section{Extended Abstract}

\section{Introduction}

Studies conducted on academic achievement of students with special needs involved in inclusion are insufficient in our country. The necessary circumstances for support services performed for students haven't been provided yet (Eripek, 2004; Kesiktaş, 2006). Although teachers were informed about special education with in-service training applications provided to especially teachers, applying the knowledge gained by teachers has not been realized fully in the classroom (Sucuoğlu \& Akalın, 2010). Thus, not offering special education support services and the permanent information about special education and effective methods intended for application to students with special needs participating in inclusion and the teachers in communication with these students in general education classrooms cause to perceive the inclusion processes as unsuccessful and prevent the practice from becoming widespread (Gürgür \& Uzuner, 2010).

As all the students, teachers and administrators, school staff, and parents of all students have become a part of this education, education of individuals with special needs is not solely a topic of concern of "Special Education" area (Güven \& Çevik, 2012). For inclusion practices are carried out in the normal educational environment, students with special needs are faced with many lessons just like any other normal peers. One of these courses is Science course that allows the formation of science literacy on students. When looked at the program of the Science course, it is seen that the needs of students with special needs are taken into consideration. In this program, for the Science literacy development of students and the formation of effective learning environments, the importance of individual differences, needs, perspectives, competences and incompetencies is stated (MEB, 2005).

\section{Method}

This research was conducted to determine the opinions of the inclusive students taking the course of science on the process of inclusion practices. The special case method, which is one of the qualitative research methods, was used in the research. A total of 7 students with special needs, including 2 with visual impairment, 2 with orthopaedic handicap, 3 with mental retardation, studying at secondary schools in Giresun city centre during 2012-2013 education year participated in this study. The names of the participants weren't used in accordance with the research ethics. Therefore, participating students was named with the codes Ö1, Ö2. The study group was selected with the help of purposive sampling method. While determining the students, it was examined whether they are inclusive students or not. All of the students are those with special needs studying at public schools. Teacher and student questionnaires consisting of open-ended questions were used as data collection tool. The questionnaire used in the research was prepared by the researcher, necessary arrangements were made in accordance with the expert opinion and the survey questions were given their final shape. The questionnaire consists of 2 parts. The first part consists of demographic information and the second part consists of a total of 7 open-ended questions for determining views regarding the inclusion process. After the questionnaire was created, it was analyzed in terms of validity firstly by a faculty member who is an expert on Special Education in Ondokuz Mayıs University, a faculty member who is an expert in Karadeniz Technical University Mentally Disabled Teaching Department and a special education teacher who is expert on his field and has worked at public schools for 15 years. In line with the feedback, the questionnaire was analyzed again with three faculty members who are experts in Giresun University Science Teaching Department. Final version of the questionnaire was applied to a total of 7 students taking the science course. Data of the research was collected, by the researcher herself with e-mail and face to face interviews. Being among the students with special needs, visually disabled students' answers were written 
by the researcher due to having insufficiencies while being passed to the questionnaire. In the study, the attention was paid to treating objectively. Duration of students' filling out the questionnaire took approximately 10-15 minutes. Data obtained from the questionnaire were identified with the themes and the categories by encoding with the contents analysis. To ensure the validity, the data was analyzed by researchers more than one. By examining the students' responses to the questions on the form in general, two researchers have decided to what the codes and the categories will be. Then, they have classified the participants' responses according to the codes and themes which are on consensus. The reliability of the research was calculated by using the formula Reliability $=$ Consensus $/$ Consensus + Dissidence.100. It's identified that matching rate between codes two researchers have done is on average level ( 80 percent) for the problems.

\section{Result and Discussion}

Answers given by the students were presented in the results section according to the frequency of use, without joining any comments, in a neutral and detailed manner. As a result of the research, students put forth that they were experiencing problems such as the lack of teacher care, unsuitability of the school books - trial exams at school-central exams applied at the stage passing to high school and being disturbed by their friends. These results suggest that inclusion practices aren't taking place profoundly also today. Besides, it was seen that the phrase they experience no problem is used by the students. One of the students who use this phrase said that he was taking Science course in support education and for this reason he doesn't have any kind of problem in terms of training. Based on this finding, the importance of supporting education in inclusion practices arises. In order for the exact realization of these practices, each individual in the process has important duties. Thus, the contribution each individual will make to the process will be a step in ensuring the success of the inclusion practices. Especially teacher's one-by-one care on students with special needs is an important factor in the success of inclusion practices. Therefore, it is thought that teachers could find the chance to care with the students with special needs more by reducing the number of students in a class with modification of physical infrastructure and by placing the inclusive students with an appropriate distribution. Thereby with the positive attitude of teachers, it could be achieved to minimize the problems of students with special needs. 